\title{
Borbáth Péter Együtt a Pörkeföldre címü meseregényének szintaktikai jellegzetességei
}

\author{
Gaál-Horváth Krisztina \\ ELTE Tanitó- és Óvóképző Kar Magyar Nyelvi és Irodalmi Tanszék
}

\begin{abstract}
Absztrakt
A dolgozat Borbáth Péter Együtt a Pörkeföldre című meseregényének szintaktikai jellemzőit mutatja be mondatgrammatikai vizsgálaton keresztül. A vizsgálat egyik fontos kérdése, hogy a szöveg párbeszédes részei mutatnak-e hasonlóságot a beszélt nyelvi dialógusokkal. A tanulmány klasszikus grammatikai keretben, a meseregény hat fejezetének felhasználásával, összesen 3205 szóból álló szövegrészletek alapján tesz megállapításokat. A vizsgálathoz kapcsolódó hipotézisek: megszakított mondatok, közbevetések főként a dialógusokban fordulnak elő; a narrációban több összetett mondat található, mint a párbeszédes részekben; a meseszöveg kevés háromnál mélyebb szintü mondatot tartalmaz; a dialógusokban több a tartalmatlan szó, és többségben vannak a rövid, tőmondatok is a leíró részekhez képest.
\end{abstract}

Kulcsszavak: szintaktikai vizsgálat, mondatgrammatika, beszélt nyelv

\section{A tanulmány célja, a vizsgálat szempontjai}

A jelen kutatás azt tűzte ki célul, hogy bemutassa, milyen szintaktikai jellemzői vannak Borbáth Péter Együtt a Pörkeföldre címü, 2019-es meseregényének. A tanulmány célja mondatgrammatikai vizsgálaton keresztül bemutatni, milyen sajátosságokkal rendelkeznek a könyv egyszerü, összetett és többszörösen összetett mondatai, illetve hogy mely szintaktikai jelenségek gyakoriak a szövegben, és ezek milyen tulajdonságokkal írhatóak le. Emellett a vizsgálat fó kérdése, hogy a szöveg párbeszédes részei vajon mennyire állnak közel a beszélt nyelvhez. A beszélt nyelvről készült részletes szintaktikai leírás (Keszler, 1983), és érdemes lehet egy esettanulmányon keresztül bemutatni, mutat-e hasonlóságokat egy írott nyelvi meseszöveg dialogikus része a beszélt nyelvi dialógusokkal.

A jelen tanulmány klasszikus grammatikai keretben, a meseregény hat fejezetének anyaga alapján tesz megállapításokat. A vizsgálat elején már körvonalazódott, hogy érdemes elkülöníteni a mesében a narrációt és a párbeszédes részeket, ugyanis elég eltérő vonásokat mutatnak. A párbeszédes részeket cél- 
szerü összevetni egyrészt Keszler Borbála vizsgálatának fent említett anyagával (Keszler, 1983), másrészt bizonyos esetekben egy úgynevezett „gazdinyelvet” vizsgáló tanulmány eredményeivel is (Horváth, 2018). Az ember-állat kommunikációt leíró anyag 2872 szót tartalmazott, ezért a jelen vizsgálat hasonló terjedelmü, összesen 3205 szóból álló szövegrészleteket használt fel.

A vizsgálathoz kapcsolódó hipotézisek a következők voltak: megszakított mondatok, közbevetések föként a dialógusokban fordulnak elő; a narrációban több összetett mondat található, mint a párbeszédes részekben; a meseszöveg a korosztályi célcsoport miatt kevés háromnál mélyebb szintü mondatot tartalmaz (azokat is inkább a leíró részekben); a dialógusokban több a tartalmatlan szó, és többségben vannak a rövid, tőmondatok is a leíró részekhez képest.

\section{A beszélt és írott nyelv szintaktikai jellemzőiről}

Beszélt nyelvnek nevezzük, amit a közvetlen (nem előkészített), kötetlen, személyes, nem hivatalos érintkezés során használ a beszélő; fö formája az élőszó, tartalmát, témáját tekintve nem korlátozott (Szalamin, 1978). Szabad, spontán, természetes, időhöz kötött, dinamikus és múlékony (Érsok, 2006). „Az elliptikusan szerkesztett mondatok túlsúlya, mondatátszövődések, közbevetett mondatok, beékelt mondattöredékek gyakori előfordulása" jellemzi (Szalamin, 1978, p. 294). A rövid szintaktikai szerkezetek, félbemaradt mondatok írott nyelvvel szembeni gyakorisága figyelhető meg benne; sokkal gyakoribbak az egyszerü, egytagú mondatok és a megszólítások, kevesebb a többszörösen összetett mondat (Érsok, 2006,). Kevés benne a többszörösen összetett mondat sok típusa, ritkák az igeneves szerkezetek, mert egyfelől a beszédnél együttesen végezzük a beszéd és a gondolkodás műveletét, [...] másfelől takarékossági tendencia is érvényesül: fölöslegesnek érezzük, ami a beszédösszefüggésből a hallgató számára már érthető, ezért mondanivalónkat grammatikailag hiányosan szerkesztjük (H. Molnár, 1961, p. 53-54). A beszélt nyelvi mondatépítés lineáris, sokszor rendezetlen, következetlen, a mondatok átszövődést tartalmaznak, redundancia- és hiányjelenségekkel terheltek (Lanstyák, 2009). Az alá- és mellérendelő összetett mondatok arányában nincsen lényeges különbség (Érsok, 2006). A beszélt nyelvi szöveget jellemzik az elmosódott mondathatárok, a lineárisan kibomló mondattípus (Szikszainé, 2006).

Írott nyelvnek azt az érvényes normának megfelelő írásos nyelvhasználatot nevezzük. amely sem térhez, sem időhöz nem kötött, statikus és állandó (Érsok, 2006). Az írott szövegben kötőszóval expliciten jelölt a mondatkapcsolás és hierarchikusan rétegződő a mondatépítés (Szikszainé, 2006). A megértést a nem nyelvi kifejezőeszközök nem segítik, ezért a tartalom maximális kifejtettségére kell törekedni a szövegalkotás során, tehát az írott nyelvi szövegek hosszabb, teljes mondatokból állnak, amelyek egymástól egyértelműen elkülöníthetők (Érsok, 2006). 


\section{Az Együtt a Pörkeföldre szövegrészleteinek szintaktikai jellegzetességei}

\section{Megszakított mondatok, közbevetések, módositó mondatrészletek}

A vizsgálathoz az Együtt a Pörkeföldre hat fejezetét használtam fel, ezek kiválasztását azok elektronikus formában történő elérhetősége befolyásolta $\mathrm{A}$ fejezetek címei és szószámai: Második rész: Borostyánállapot (503 szó címmel együtt); Harmadik rész: Az álommángorlás előnyeiről (409 szó címmel együtt); Kilencedik rész: A zajkereskedő érkezése (751 szó címmel együtt); Tizedik rész: Mirminyó álma (569 szó címmel együtt); Tizenegyedik rész: Elhagyni bunkert, barlangot (608 szó címmel együtt) és Tizenkilencedik rész: A pörkeföldi piacon (365 szó címmel együtt). A teljes anyag 3205 szót tartalmazott. A szövegrészeket minden esetben összevetettem a nyomtatott könyv anyagával (Borbáth, 2019), és ahol eltérés mutatkozott, a nyomtatott példányban szereplő változat került be a vizsgálandó anyagba. A fejezetek mondatgrammatikai vizsgálata Keszler Borbála említett tanulmányának szempontjai alapján (Keszler, 1983) készült. Az elemzés során különválasztottam a párbeszédes és a leíró részeket, ezek aránya a fejezetekben a következő: a narráció 2137 szóból (66,67\%), a párbeszédek 1068 szóból (33,32\%) állnak. Hasonló vizsgálatokat végzett V. Raisz Rózsa, aki például Petelei István, Kaffka Margit és Krúdy Gyula 5-5 novelláját vizsgálta hozzávetőlegesen 10000 szövegszónyi anyag alapján, ott a narráció és a „szereplő beszédének" aránya: Petelei: 44,7\% és 36,46\%; Kaffka: 48,55\% és 33\%; Krúdy: 68,68\% és 27,96\% (Raisz, 1989, p. 322).

Az első vizsgálati szempont a megszakított mondatok, közbevetések, módosító mondatrészletek és „szabálytalan szerkesztésmódok” kérdésköre. Megszakított mondat összesen négy található az anyagban, mind a párbeszédes részek között, a cselekmény időrendjében az első: - De én tudok egy helyet... - ezt maga a beszélő fejezi aztán be kicsit más formában: - Én tudom, hogy hova mehetnétek. A második: - Akkor elég csak odáig mennünk és minden gondunk megoldódik... Itt egyrészt elgondolkodást, egy gondolatmenet végét jelzi a megszakadás, másrészt egy szereplő oldalba böki a beszélöt, amivel kizökkenti őt, és megcáfolja a mondandóját. A harmadik: - De ide nem biztos, hogy... Ezt a dialógus másik résztvevője fejezi be, szinte belevágva a beszélő szavába: - Tudom, ide nem biztos, hogy visszajövünk. A negyedik: - Semmivel, Zazil, semmivel... Ennél a megnyilatkozásnál a megszakadás szintén elgondolkozást jelent, a gondolatmenetet maga a beszélő folytatja más irányban.

Közbevetések és módosító mondatrészletek leginkább szintén a párbeszédes részekben találhatók, ilyenek például: - Hát, mire kiklopfolod a fejemből az álmokat, semmi nem marad a fogsoromból meg a koponyámból; - Ja, azt még nem mutattam?; - Ha jól belegondolsz, ezzel a szippantóval és az álommángorlóval meg lehet találni a megoldást a világ minden bajára! A 
narrációban egy-két hasonló fordul elő: És különben is, hova tegye őket majd az új otthonában?; Második: vagy inkább és föleg! Keszler Borbála említi még a logikátlan, csapongó mondatszövést, a mondatok többszöri elkezdését és az olykor egész fömondatok kihagyását (Keszler, 1983, p. 182). A többszörös kezdés elég jellemző a párbeszédes részekre, például: - Aztán meg, aztán meg neked nincs is túl sok problémád; - Ne mozduljatok, mindjárt, hmm, mindjárt megmutatom!; - Pörke, igen, a nagyapám is pörke volt! - Ezek, ezek nagyon sokan vannak! Az első hipotézis tehát beigazolódott, a dialógusokban nagyobb számban fordulnak elő megszakított mondatok, közbevetések és módosító mondatrészletek, mint a leíró részekben.

\section{Mondathosszúság és szerkesztettségi mutató}

A mondathosszúság vizsgálata az egyszerủ és összetett mondatok számát és arányát jelenti a szövegben. A szerkesztettségi mutató Keszler Borbálánál a mondategység (egy alany-állítmányi szerkezet, tehát egy egyszerű mondat vagy tagmondat) és a mondategész (mondatkezdő nagybetűtől a mondatzáró írásjelig tartó egység, tehát egyszerủ vagy összetett mondat) hányadosa (Keszler, 1983). A vizsgált részek az Együtt a Pörkeföldre című meséből öszszesen 302 mondatot tartalmaznak, ebből a leíró rész 179, a párbeszédes rész 123 mondatból áll, számottevő eltérés tehát arányaiban nincsen. A mondathosszúság a következőképpen alakul a két részben: a narráció 67 egyszerü mondatot tartalmaz, és összesen 112 összetett mondatot. Ebből a kéttagú, két tagmondatból álló összetett mondat 53, a többi 59 többszörösen öszszetett mondat; három tagmondatból áll 32, négy tagmondatból 19, öt tagmondatból 7 és hét tagmondatból egy. Fontos megemlíteni, hogy nem csak a párbeszédeket bevezető (például: Erre Bocskoján tudálékosan magyarázni kezdte:), hanem az őket megszakító vagy lezáró idéző mondatok (például: - szontyolodott el Mirminyó - vagy - tiltakozott Zazil) is mind a leíró részekhez kerültek, ez lehet az egyik oka a narrációban előforduló egyszerű mondatok magas számának. A párbeszédes részek 60 egyszerű mondatot és összesen 63 összetett mondatot tartalmaznak, ebből a két tagmondatból álló összetett mondat 42. A többszörösen összetett mondatok közül három tagmondatból áll 14, négyből, ötből és hatból 2, valamint itt is van egy hét tagmondatból álló mondat.

Látjuk, hogy a narráció több összetett mondatot tartalmaz, mint a párbeszédes részek (a mondatok 62,57\%-a szemben a mondatok 51,22\%-ával), és a leghosszabb mondata hét tagmondatból áll: Helyzet volt, amin úrrá kellett lenni, ügy, amit meg kellett oldani, Bocskoján, Zazil és Tivonul Buffogó önfeledten vitatkozott arról, hol lehetne elhelyezni a zajgyüjteményt, hogy mit kéne csinálni Ushguli vezetőivel. A párbeszédes részek arányaiban több egyszerü mondatot tartalmaznak (48,8\% és 37,5\%), viszont itt is hét tagmondatból áll a leghosszabb összetett mondat: - Aztán meg (...), aztán meg neked nincs is túl sok problémád, Tivonul, se házad, amit rendben kell tartanod, 
se családod, akikröl gondoskodnod kell, se munkád, amit elvégeznél! Itt kell megemlíteni, hogy a szervetlenül kapcsolódó tagmondatok (mint például a fenti mondatban található megszólítás, vagy az olyan mondatszók, mint hát, ja, igen stb.) nem kerültek be a számlált tagmondatok közé. Keszler Borbála beszélt nyelvi anyagában az egyszerü mondatok voltak túlnyomó többségben (57,40\%) (Keszler, 1983, p. 189), ez jóval magasabb a párbeszédes részek százalékos adatánál.

A szerkesztettségi mutató az Együtt a Pörkeföldre egész vizsgált anyagában a következő: a teljes anyag 610 alany-állítmányi szerkezetből, tagmondatból áll, ezt kell elosztani a mondatok számával (302), így a szerkesztettségi mutatója 2,01. A narráció 387 alany-állítmányi szerkezetet tartalmaz, a szerkesztettségi mutatója 2,16, míg a párbeszédes részek 223 alany-állítmányi szerkezetből állnak, így ennek a szerkesztettségi mutatója 1,81. Érdekes, hogy Keszler Borbálánál a beszélt nyelv szerkesztettségi mutatója 1,86 lett (Keszler, 1983, 189). - az érték igen hasonló a párbeszédes részekéhez. Deme László vizsgálta a szépirodalmi próza mutatóját két 100000 betűhelynyi anyag, Fejes Endre és Németh László mủvei alapján (kihagyva a szereplők beszéltetéseit és az ezeket bevezető, megszakító, befejező idéző mondatokat), ezekben az érték 1,90 és 3,41 lett (Deme, 1971, p. 148-149). Ez az Együtt a Pörkeföldre narrációjának mutatójához áll közelebb.

\section{A mellé- és alárendelö összetett mondatok aránya}

Az összetett mondatok vizsgálatakor néha nem teljesen egyértelmü, mit is tekintsünk alárendelő és mellérendelő összetett mondatnak, illetve mihez kezdünk a szervetlenül kapcsolódó tagmondatokkal. Ez utóbbiba többek között azok a mondatok is beletartoznak, amelyek olyan elöre-, közbe- és hátravetések, amelyek „nem grammatikai, hanem kommunikatív, szemantikai kapcsolatban vannak csak a mondattal” (Keszler, 2000, p. 552). Legtöbbször „a közlés egészére vagy komplexebb darabjára” vonatkoznak, és „gyakran főmondat jellegűek" (Keszler, 2000, p. 552). A funkciójuk sokféle lehet, tipizálásuk túlmutat a jelen dolgozat keretein. A vizsgálat során csak azokat a mondatokat tekintettem alárendelőnek, amelyek esetében egyértelmű volt az utalószó és a mellékmondat mondatrészkifejtése, mellérendelőnek pedig azokat, amelyekben a mellérendelő kötőszó benne volt, vagy magától értetődően lehetett vele kiegészíteni a mondatot. A semleges kapcsolások nem kerültek egyik kategóriába sem.

A jelöletlen ok-okozati kapcsolatról nehéz eldönteni, hogy magyarázó mellérendelésről vagy okhatározói alárendelésről van szó; ha nem volt utalószó a főmondatban, ezeket kivétel nélkül mellérendelésnek vettem, mert lazább kapcsolatot éreztem a tagmondatok között. Emellett nagyon sok a kettősponttal bevezetett tagmondat a szövegben; ezek besorolásakor igyekeztem nem csak a grammatikai, hanem a tagmondatok tartalma közötti logikai viszony alapján is dönteni. Ilyenek például: És akkor Niru egyszerre 
megértette: neki is mennie kell, hacsak nem akarja magukra hagyni a megszelíditett zajokat (tárgyas alárendelő); Niru és Bocskoján átmentek Zazilhoz, aki nagy munkában volt: precizen összetekerte a nélkülözhetetlen találmányok tervrajzait (...) (magyarázó mellérendelö); Bocskoján teljesen össze volt zavarodva: Mirminyó gond nélkül hagyja itt egy élet munkáját (...) (okhatározó alárendelö) stb.

Ezek alapján összesen az Együtt a Pörkeföldre vizsgált részleteiben 164 mellérendelés és 146 alárendelés található a tagmondatok között (a többszörösen összetett mondatokat is beleszámolva). A narráció 112 összetett mondata (387 tagmondata) 118 mellérendelő és 97 alárendelő tagmondatból áll. A párbeszédes részek 63 összetett mondata (223 tagmondata) 46 mellérendelő és 49 alárendelő tagmondatot tartalmaz. Látható, hogy a leíró részekben több az alárendelés, mint a mellérendelés, de a különbség nem számottevő. A párbeszédes részekben a két érték szinte azonos. Keszler Borbála azt írja, a beszélt nyelvben a mellérendelt és az alárendelt összetett mondatok gyakoriságában nincs lényeges különbség (Keszler, 1983, p. 191), és a saját vizsgálata alapján is erre a következtetésre jut. A párbeszédes anyag alapján is ezt látjuk.

\section{Mondatátszövödés az anyagban}

Az Együtt a Pörkeföldre hat vizsgált fejezetének anyagában (3205 szó), és valójában a teljes mesekönyvben is csupán négy mondat tartalmaz átszövődést. Ebből három az Elhagyni bunkert, barlangot, egy pedig A pörkeföldi piacon fejezetben található. A mondatok közül egy van a leíró rész mondatai között: Itt mindennek megvolt a helye, de ott azt sem tudhatja, mi vár majd rá. $\rightarrow$ Itt mindennek megvolt a helye, de azt sem tudhatja, ott mi vár majd rá. Az átszövődés kicsit kérdéses (határeset) a mondatban, ugyanis a fómondatban is lehet értelmezni az átszövődött mondatrészt. Az alárendelés tárgyas (kitett utalószóval), az alaptag a tud, tárgyi mellékmondatból helyhatározó szövődik át helyhatározóként, nem változik a szintaktikai szerepe.

A másik három átszövődéses mondat a párbeszédes részekben található. A mondatok: - De ide nem biztos, hogy... [visszajövünk] $\rightarrow-$ De nem biztos, hogy ide... [visszajövünk]; - Tudom, ide nem biztos, hogy visszajövünk. $\rightarrow$ Tudom, nem biztos, hogy ide visszajövünk; - A te fantasztikus álomszipkáddal és az álommángorlóddal azonban lehet, hogy több sikerünk lenne. $\rightarrow-$ Azonban lehet, hogy a te fantasztikus álomszipkáddal és az álommángorlóddal több sikerünk lenne. Az első két mondat lényegét tekintve ugyanaz; Bocskoján mondata megszakad, Mirminyó fejezi be a gondolatot. A mondatok alanyi alárendelésủek, alaptagjuk a biztos, alanyi mellékmondatból szövődik át helyhatározó a fömondatba, változatlan szintaktikai szerepben. A harmadik mondat szintén alanyi alárendelésü, alaptagja a lehet, egész szintagmabokor szövődik át benne az alanyi mellékmondatból a fömondatba (az alaptag eszközhatározó, a szintaktikai szerepe nem változik). Az ember-állat kommu- 
nikációs vizsgálatban öt kísérlet lejegyzett anyagából (2872 szó) csupán egy mondat tartalmazott átszövődést: Jó, hát ez így belement a szádba, igen, ez nem biztos, hogy ér (Horváth, 2018, p. 284).

\section{A szintezödés}

A szinteződés vizsgálata azt mutatja meg, hány szintű mondategészek fordulnak elő az anyagban. Az Együtt a Pörkeföldre vizsgált részeiben a mondatok nagy többsége egy-, illetve kétszintű. Összesen 20 háromszintű mondat van a teljes anyagban, négyszintű pedig csupán kettő. A leíró részekben egyszintü például: Mindenki mélán nézett maga elé, önkéntelenül mosolygott, Mirminyó pedig pillanatokon belül elaludt. Kétszintü: Miközben Tivonul az utazás unalmas, praktikus részleteit tárgyalta meg Zazillal, Bocskoján azon agyalt, hogy tudna minél több demizsont meg hordót magával cipelni. Háromszintű 17 mondat a narrációban, például: Niru nagyon örült, hogy így együtt lehetnek, hogy most tényleg mindenki itt van, aki fontos neki. Két négyszintü mondat van a leíró részben, ezek: És annyira vágyott arra a tájra, arra az illatos, szagos országra, ahol született, hogy úgy érezte, ha most nem indul neki, soha többé nem fog már eljutni oda; Megkérte Zazilt, zárja le neki valahogy a barlangját, hogy ha egyszer mégis vissza tudnának jönni, meglegyen nekik ez a hely.

A párbeszédes részekben egyszintủ mondat például: - A tavakig eljuthatunk pár hét alatt, de nem lesz egyszerü út. Kétszintü: - Titeket is bosszant, amikor ébredés után összekuszálódnak az álmaitok? Háromszintü csupán három mondat volt a párbeszédes részekben, ezek: - Ez itt az álomszipka, úgy kiszippantja az orrodon keresztül az álmaidat, mintha soha ott se lettek volna!; - Tudom, ide nem biztos, hogy visszajövünk; - Kérlek, Zazilnak van egy ilyen álomveröje, amivel kiklopfolja a fejedböl, ami benne van, és utána azokat össze lehet hasonlitani, például kiderült, hogy NEKEM vannak a legesleggyőztesebb álmaim. Ez utóbbi mondat jól példázza, mennyire közel is állnak a mese párbeszédes részei a beszélt nyelvhez.

Keszler Borbála anyagában a felvételről nem tudók beszédében ötnél mélyebb szintü mondat csak egy volt, a felvételt készítők mondatai pedig mind egy- és kétszintűek voltak (Keszler, 1983). Az interspecifikus kommunikáció során elhangzott szövegek az esetek túlnyomó többségében ugyanúgy egyés kétszintü mondatokat tartalmaznak, mint a dialogikus szövegek, aminek oka a szövegek jellege: nagyon sok az utasítás, a kérés, parancs, szinte egyáltalán nincsenek leíró vagy narratív részek, a beszélő rövidségre, gyors információcserére törekszik (Horváth, 2018).

\section{A mondatterjedelem, a telitettségi mutató és az egyszerü mondat}

A mondatokban található tartalmas szavak száma mutatja a mondatok terjedelmét. Tartalmatlan szónak tekintettem mindent, ami nem alapszófajú szó, ez alapján a leíró részekben összesen 550, a párbeszédes részekben 344 
tartalmatlan szó található, tehát a teljes 3205 szóból álló anyagban 894. A teljes anyagban a tartalmas szavak száma így 2311 , ez a szavak $72,11 \%$-a. A narráció 2137 szavából 1587, a párbeszédes részek 1068 szavából 724 tartalmas, ez 74,26\% és 67,79\%. Számottevő különbség nincs, mégis látszik, hogy a párbeszédes részekben több a tartalmatlan szó, mint a leíró részekben.

Az egy mondatra jutó átlagos szómennyiség adja meg a telítettségi mutatót. A teljes vizsgált anyag az Együtt a Pörkeföldre címü meséből 302 mondatból áll, a narráció 179 mondatból, a párbeszédes részek 123 mondatból. Az egy mondategészre eső telítettségi mutató a teljes anyagban 7,65; a leíró részekben 8,86 , a párbeszédes részekben 5,88 . Az egy mondategységre eső telítettségi mutató a teljes vizsgált anyagban (610 tagmondat) 3,78; a narrációban (387 tagmondat) 4,10, a párbeszédes részekben (223 tagmondat) 3,24. Keszler Borbála beszélt nyelvet vizsgáló anyagában az egy mondategészre eső telítettségi mutató 5,17, az egy mondategységre eső 2,78 (Keszler, 1983). Látható, hogy ezek az értékek a párbeszédes részek értékeihez állnak közelebb. Deme László többféle prózát vizsgáló könyvében a szépirodalmi szövegek telítettségi mutatója 7,27 és 19,87. az egy mondategységre jutó átlagos szómennyiség 3,82 és 5,80 (Deme, 1971, p. 314)..

A Keszler Borbála által vizsgált kötetlen beszélgetésekben 57,40\% volt az egyszerű mondatok aránya (Keszler, 1983). Az Együtt a Pörkeföldre teljes vizsgált anyagában 42,05\% az egyszerü mondatok aránya (127 egyszerü mondat), a leíró részben ez 37,43\%, a párbeszédes részekben 48,78\%. Látható, hogy a párbeszédes részek jóval több egyszerű mondatot tartalmaznak, még úgy is, hogy a narrációban elég nagy számban vannak az idéző mondatok. Keszler Borbála azt állapítja meg, hogy „a beszélt nyelvre jellemzőek az ultrarövid mondatok (vagyis az egy-, két- és háromszavas mondatok)" (Keszler, 1983, p. 200). Ez hatványozottan jellemző az ember-állat kommunikációban elhangzó szövegekre is (Horváth, 2018). Az Együtt a Pörkeföldre mondataira az ultrarövidség nem jellemző, viszont a nagyon hosszú egyszerű mondatok sem.

\section{Az eredmények összegzése}

A dolgozat fő kérdése az volt, hogy milyen szintaktikai jellemzői vannak Borbáth Péter Együtt a Pörkeföldre című meseregényének a vizsgált hat fejezet alapján, illetve hogy a szöveg párbeszédes részei mennyire állnak közel a beszélt nyelvi dialógusokhoz. A vizsgálathoz kapcsolódó hipotézisek beigazolódtak: a dialógusokban nagyobb számban fordultak elö megszakított mondatok, közbevetések és módosító mondatrészletek, mint a leíró részekben. A narrációban több összetett mondat található, mint a párbeszédes részekben; a meseszöveg a korosztályi célcsoport miatt kevés háromnál mélyebb szintű mondatot tartalmaz, többségüket a leíró részekben. A dialógusokban több a tartalmatlan szó, mint a narrációban, és többségben vannak bennük a rövid, tőmondatok is. 
Megállapítható még, hogy az anyagba tartozó szövegek párbeszédes részei sok tekintetben közel állnak a beszélt nyelvi dialógusokhoz, sokkal több jellemzőjüket mutatják, mint a leíró, narráló részek. További vizsgálatokat mindenképp érdemes lenne végezni a témában; a meseszövegek rengeteg, nyelvészeti szempontból is érdekes jellegzetességgel rendelkeznek.

\section{Irodalom}

Deme, L. (1971). Mondatszerkezeti sajátosságok gyakorisági vizsgálata. Akadémiai Kiadó.

Érsok, N. Á. (2006). Szóbeliség és/vagy írásbeliség. Magyar Nyelvőr, 130(2), 165-176.

Horváth, K. (2018). Az interspecifikus kommunikáció szintaktikai jellegzetességeiről. In Balázs, G. \& Lengyel, K. (Eds.) Grammatika és oktatás - idöszerü kérdések (pp. 277-286). ELTE BTK Mai Magyar Nyelvi, Tanszék és Inter (IKU) és Magyar Szemiotikai Társaság.

H. Molnár, I. (1961). A beszédtöltelékekről - más szempontból. Magyar Nyelvőr, 85(1). 51-55.

Keszler, B. (1983). Kötetlen beszélgetések mondat- és szövegtani vizsgálata. In Rácz,

E. \& Szathmári, I. (Eds.), Tanulmányok a mai magyar nyelv szövegtana köréböl (pp. 164-202). Nemzeti Tankönyvkiadó.

Keszler, B. (2000). Többszörösen összetett mondatok elemzése. In Keszler Borbála (Ed.), Magyar grammatika (pp. 542-554). Nemzeti Tankönyvkiadó.

Lanstyák, I. (2009). A magyar beszélt nyelv sajátosságai. Stimul.

Raisz Rózsa (1989). Mondatszerkezeti jellemzők gyakorisági vizsgálata PeteleiKaffka- és Krúdy novellákban. In Fábián, P. \& Szathmári, I. (Eds.), Tanulmányok a századforduló stílustörekvéseiből (pp. 317-338). Tankönyvkiadó.

Szalamin, E. (1978). A mai magyar beszélt nyelv mondattanának kérdéséhez. Magyar Nyelv, 74(3). 293-303.

Szikszainé Nagy, I. (2006). Leíró magyar szövegtan. Osiris Kiadó. 


\section{Gaál-Horváth, K.}

\section{Syntactic characteristics of Péter Borbáth’s Együtt a Pörkeföldre}

The present paper analyses the syntactic features of Péter Borbáth's book for 6- to 10-year-olds Együtt a Pörkeföldre [Together to Scurfland], including the important issue of how closely the story's dialogues resemble those of the spoken language. The paper employs a traditional grammatical framework to examine six chapters (3205 words) of the tale. Hypotheses: interrupted sentences and inset sentences occur chiefly in dialogues; the more complex sentences occur in the narrative parts; few sentences are deeper than three levels; 'empty' words and short, simple sentences occur more in the dialogues.

Keywords: syntactical analysis, sentence grammar, spoken language 